\title{
Contents of Volume 12
}

Ahola, M.: Redescription of the larva of Siobla ruficornis (Gimmerthal, 1834) (Hymenoptera, Tenthredinidae) from East Finland 28-32

Chen, X., He, J., van Achterberg, K. \& Ma, Y.: A new species of the genus Cryptoxilos Viereck (Hymenoptera: Braconidae: Euphorinae) from China .......... 108-111

Disney, R. H. L., Zvereva, E. L. \& Mostovski, M. B.: A scuttle fly (Diptera: Phoridae) parasitizing a beetle (Coleoptera: Chrysomelidae) in Russia .......... 59-63

Heikinheimo, O.: Semiaphis nolitungere Aizenberg, 1954 and differences between the genera Semiaphis van der Goot, 1913 and Hyadaphis Kirkaldy, 1904 .... 39-43

Junnilainen, J.: Two new species of Swammerdamia from the southern Ural Mountains and southern Siberia (Lepidoptera: Yponomeutidae) ................... 112-118

Jussila, R.: Pionini species (Hymenoptera, Ichneumonidae, Clenopelınatinae) new to Finland ............... 119-120

Jussila, R.: Additions to the revision of the genus Atractodes (Hymenoptera: Ichneumonidae) of the Palaearctic Region. III 193-216

Kaila, L., Bengtsson, B. Å., Šules, I. \& Junnilainen, J.: A revision of the Elachista regificella Sircom -complex (Lepidoptera: Elachistidae) ........................ 153-168

Kobro, S.: Hoplotwips polysticti (Thysanoptera) on the wood-rotting polypore Trichaptum abictinum infesting dead Picea ubies in Norway

Komonen, A., Siitonen, J. \& Mutanen, M.: Insects inhabiting two old-growth forest polypore species ............ 3-14

Leppii, M. \& Hämäläinen, H.: Zavreliclla marmorata (v.d.Wulp, 1859) (Diptera: Chironomidae) - a chironomid species new to Finland from Lake Pohjalampi, North Karelia 4445

Martikainen, P. \& Koponen, M.: Meteorus corax Marshall, 1898 (Hymenoptera: Braconidae), a new species to Finland and Russian Karelia, with an overview of northern species of Metcorus parasitizing beetles ......

169-172

Niemi, R.: Atopochthonius artiodacty/us Grandjean, 1948 (Acari: Oribatida) found for the first time in Finland.

173-175

Nilsson, A. N.: A new Gyrinus species from Mongolia (Coleoptera: Gyrinidae). $121-124$

Nupponen, K.: Records of scythridids from Tunisia, with description of two new species (Lepidoptera: Scythrididae). $53-58$

Nupponen, K. \& Ahola, M.: Notes on the biology of Plersphorus rolgensis (Möschler, 1862) with description of the larval stage (Lepidoptera, Pterophoridae)

Nupponen, K. \& Nupponen, T.: Pterophorus poculidactyla sp. n. from the Altai Mountains (Lepidoptera: Pterophoridae) ........................................... 50-52

Nupponen, K. \& Nupponen, T.: Notes on the scythridid fauna of the Altai Mountains, with description of four new species (Lepidoptera: Scythrididae) ........ 81-93

Nupponen, K., Ahola, M. \& Kullberg, J.: Agrotis iremeli sp. n. from the southern Ural Mountains, with description of the larval stage (Lepidoptera: Noctuidae) 217-226

Nupponen, K., Junnilainen, J., Nupponen, T. \& Olschwang, V.: The cochylid fauna of the Southem Ural Mountains, with description of Cochylimorpha ignicolorana Junnilainen \& K. Nupponen sp. n. (Lepidoptera: Tortricidae: Cochylini) 94-107

Roininen, H., Tahvanainen, J., Vikberg, V. \& Zinovjev, A.: Salix aurita - the correct food plant for Eurra cinereat Kopelke, 1996 (Hymenoptera: Tenthredinidae) ....

$129-130$

Rydell, J., Fagerström, J., Andersson, S., Stille, G. G., Gelang, M., Lancaster, W. C., Svensson, M. G. E. \& Tullberg, B. S.: Convergence in wing coloration between orange underwing moths (Archiearis spp.) and tortoiseshell butterflies (Ag/ais spp.) 65-71

Rydel\}, J., Roininen, H., Philip, K. W. \& Karhu, A.: Lepidoptera collected in the Canadian Arctic during the Tundra Northwest 99 expedition .......... 131-138

Salmela, J.: Adult craneflies (Diptera: Nematocera) around springs in southern Finland. 139-152

Silfverberg, H.: Walter Hackman (1916-2001) .. 182-192

Siltverberg, H.: Changes 1996-2000 in the list of Finnish insects ..................................................... 227-243

Várkonyi, G. \& Ahola, M.: Notes on the larval biology of Xestia borealis (Lepidoptera: Noctuidae) ....... 78-80

Vikberg, V.\& Koponen, M.: Two dryinid species new for Fennoscandia with a re-evaluation of the generic division of N. European Gonatopodinae (Hymenoptera, Dryinidae) 33-38

Vikberg, V. \& Koponen, M.: Proclithrophorus genalis sp. n. from northein Finland representing a genus new to European fauna (Hymenoptera: Braconidae: Euphorinae)... 176-181

Vilkamata, P. \& Komonen, A.: Redescription and biology of Trichosia (Bueosciara) sintata Menzel \& Mobrig (Diptera: Sciaridae) $46-49$

Wahlberg, N.: On the status of the scarce fritillary Euphydryas matuma (Lepidoptera: Nymphalidae) in Finland 244-250

Wahlberg, N., Kullberg, J. \& Hanski, I.: Natural history of some Siberian melitaeine butterfly species (Nymphalidae: Melitaeini) and their parasitoids 72-77 


\section{Book reviews}

Asher, J., Warren, M., Fox, R., Harding, P., Jeffcoate, G. \& Jeffcoate, S. 2001: The Millenium Atlas of Butterflies in Britain and Ireland 125

Dempster, J. P. \& McLean, I. F. G. (eds.) 1998: Insect Populations in Theory and Practice 126

Ole Fogh Nielsen 2000: De danske græshopper Danmarks Dyreliv, Bind 9 [Danish Grasshoppers. Animal Life of Denmark, vol. 9]
Guppy, C. S. \& Shepard, J. H. 2001: Butterflies of British Columbia...

251

Tolman, T. 2001: Photographic guide to the butterflies of Britain \& Europe 252-253

\section{Other}

Corrigenda 64

Erratum 254 